\title{
Primary lymphoma of the liver: A case report and review
}

\author{
Franzjosef Schweiger MD FRCPC FACP FACG, Rowen Shinder MD FRCPC, Sheldon Rubin MD FRCPC
}

\begin{abstract}
F Schweiger, R Shinder, S Rubin. Primary lymphoma of the liver: A case report and review. Can J Gastroenterol 2000;14(11):955-957. The case of a previously healthy man who developed primary non-Hodgkin's lymphoma of the liver is presented. Biopsy confirmed that the tumour was of the diffuse large cell type and was of apparent T-cell origin. The diagnosis of these rare tumours is suggested by the presence of a hepatic mass without lymphadenopathy, splenomegaly or bone marrow involvement, as well as normal carcinoembryonic antigen and alpha-fetoprotein levels. However, histological examination of tissue is essential to confirm the diagnosis. The response to treatment varies, but surgical resection and/or chemotherapy can result in prolonged remissions. The literature on this topic is briefly reviewed.
\end{abstract}

Key Words: Liver mass; Primary hepatic lymphoma

\section{Lymphome primitif du foie : Rapport de cas et revue de la littérature}

RÉSUMÉ : On présente ici le cas d'un homme auparavant en bonne santé qui a développé un lymphome du foie nonhodkinien. La biopsie a confirmé qu'il s'agissait d'une tumeur diffuse à grosses cellules, apparemment liée aux lymphocytes $\mathrm{T}$. On peut diagnostiquer de telles tumeurs par la présence d'une masse au foie sans lymphadénopathie, splénomégalie ni atteinte de la moelle osseuse, en présence de taux normaux d'antigène carcino-embryonnaire et d'alpha-fœetoprotéine. Par contre l'examen histologique des tissus est essentiel pour confirmer le diagnostic. La réponse au traitement varie, mais la résection chirurgicale et (ou) la chimiothérapie peuvent entraîner des rémissions prolongées. Le présent article passe brièvement en revue la littérature à ce sujet.
$\mathrm{L}$ iver involvement in non-Hodgkin's lymphoma is common and occurs in more than $50 \%$ of patients $(1,2)$. However, primary hepatic lymphoma (PHL) is rare in the absence of systemic involvement, and fewer than a hundred such patients have been described in the literature. Most cases before 1980 were reported in autopsy studies, but in the past two decades, diagnostic imaging and tissue sampling suggest an increasing frequency of this tumour, especially in the setting of immunosuppression (3-8).

We report a case of PHL in a previously healthy patient and briefly review the literature on this topic.

\section{CASE PRESENTATION}

A 40-year-old, previously healthy, white man presented with a 10-week history of generalized malaise, anorexia, nausea, epigastric pain and weight loss of $7 \mathrm{~kg}$. The pain was persistent, radiating into the back, worse postprandially and, at times, awakening him at night. He found no relief with a histamine $_{2}$-receptor antagonist. He denied intake of other medications or alcohol, but smoked 20 cigarettes/day. There was no history of fever, night sweats or jaundice, and he had no risk factors for viral hepatitis. On admission to hospital, the physical examination revealed epigastric tenderness but no palpable mass, lymphadenopathy, hepatosplenomegaly or peripheral stigmata of chronic liver disease.

Initial laboratory studies showed normal complete blood counts, and normal bilirubin and transaminase levels. The serum alkaline phosphatase level was mildly elevated at $150 \mathrm{U} / \mathrm{L}$ (normal is 39 to $117 \mathrm{U} / \mathrm{L}$ ) as was the lactate dehydrogenase level at $255 \mathrm{U} / \mathrm{L}$ (normal is 70 to $242 \mathrm{U} / \mathrm{L}$ ). The level of C-reactive protein was $92 \mathrm{mg} / \mathrm{L}$ (normal is 0 to $10 \mathrm{mg} / \mathrm{L}$ ). Serum carcinoembryonic antigen and alpha-fetoprotein levels were normal. Serological tests for the hepatitis B virus, hepatitis $\mathrm{C}$ virus (HCV), Epstein-Barr virus and human immunodeficiency virus were negative.

A computed tomography (CT) scan of the abdomen demonstrated a mass approximately $10 \mathrm{~cm}$ in diameter, involving the caudate and part of the right lobe of the liver (Figure 1). It was of decreased attenuation compared with the surrounding liver, and its contour was ill defined. There was no intraabdominal lymphadenopathy. Other imaging studies included CT scans of the chest and neck, a small bowel followthrough, and a bone scan, all of which were normal. A gallium scan showed increased uptake of isotope within the upper portion of the central abdomen corresponding to the liver mass. An upper endoscopy was unremarkable.

Departments of Internal Medicine and Pathology, South East Health Care Corporation, The Moncton Hospital, Moncton, New Brunswick

Correspondence and reprints: Dr Franzjosef Schweiger, 100 Arden Street, Suite 405, Moncton, New Brunswick E1C 4B7.

Telephone 506-858-8441, fax 506-858-0859, e-mail schweig@nbnet.nb.ca

Received for publication August 11, 1999 Accepted September 7, 1999 


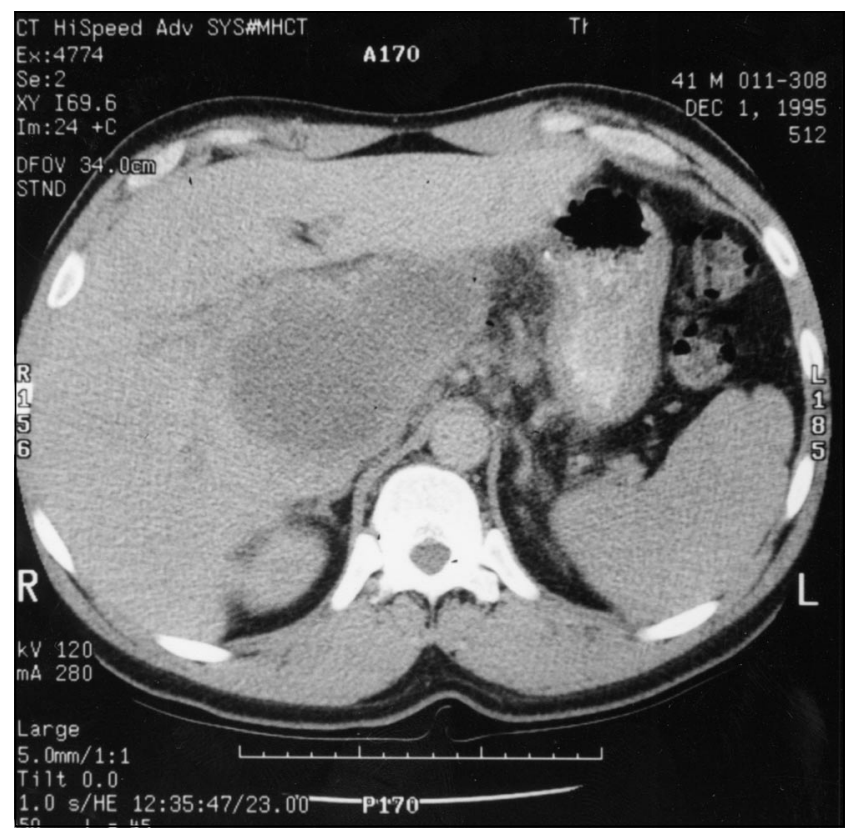

Figure 1) Contrast-enhanced computed tomography scan of the abdomen showing a large solitary defect of low attenuation involving the caudate and adjacent right lobe of the liver $(10 \times 7 \mathrm{~cm})$. The mass extends inferiorly and compresses the region of the duodenum

Histological examination of the liver biopsy specimens obtained by needle aspiration under CT guidance revealed a diffuse large cell type of non-Hodgkin's lymphoma (Figure 2). Tumour cells were positive for leukocyte common antigen and UCHL-1, and were focally positive for CD-3 and MT1. The cells were negative for epithelial membrane antigen, cytokeratin and alpha-fetoprotein, suggesting that the neoplasm was of T-cell origin. Bone marrow aspiration and biopsy did not show any involvement by the lymphoma.

The patient initially was treated with four courses of cyclophosphamide, doxorubicin, vincristine and prednisone, but improved only temporarily. A repeat evaluation by CT scan five months after his initial admission revealed progression of the tumour, and despite further aggressive chemotherapy, he developed profound jaundice, ascites and renal failure, and died two months later.

\section{DISCUSSION}

First described in 1965 by Ata and Kamel (9), PHL is not a common hepatic neoplasm. It frequently occurs in the fourth decade of life, with a four to one male preponderance (6). Abdominal pain, hepatomegaly, fever, night sweats and weight loss are the presenting clinical features in the vast majority of patients (6) but are nonspecific. Hepatocellular carcinoma, a much more common liver neoplasm, often presents in the same manner. Unusual presentations of PHL include jaundice and ascites (7), thrombocytopenia $(10,11)$, hypercalcemia $(12)$ and acute fulminant hepatic failure (13).

In the past decade, an increasing number of cases of PHL have occurred in immunocompromised patients, particularly in those with the human immunodeficiency virus $(8,14)$.



Figure 2) Specimen of hepatic tumour obtained by computed tomography-assisted needle biopsy (hematoxylin and eosin stain, original magnification $\times 400$ ). Shown are atypical, large-type lymphoma cells with adjacent hepatocyte necrosis surrounding a central vein

Laboratory investigations typically show an elevated lactate dehydrogenase level, and normal or mildly abnormal serum alkaline phosphatase and transaminase levels; however, tests are typically negative for conventional tumour markers such as carcinoembryonic antigen and alpha-fetoprotein $(3,5)$.

In most cases, the lymphoma is evident on imaging studies as a solitary mass in the liver, although multiple discrete lesions have also been described, especially in immunosuppressed patients $(8,15)$. Rarely is there diffuse infiltration of the liver by the tumour $(3,4,6,13)$. Although there is not a single characteristic imaging finding of $\mathrm{PHL}$, a homogeneous hypoechoic lesion on ultrasonography combined with a solid low attenuation defect on a CT scan is very suggestive of PHL (15). A definitive diagnosis can be reached only by examination of histological material obtained either by percutaneous biopsy or laparotomy.

Most reported lesions are large cell lymphomas, and immunohistochemical analysis is necessary to distinguish these tumours from poorly differentiated carcinomas. In the patient described in this report, the abnormal cells stained positively for leukocyte common antigen and negative for epithelial markers, confirming the diagnosis of lymphoma. Immunophenotyping suggested that the tumour was of $\mathrm{T}$ cell origin. In the literature, about $80 \%$ of PHLs are B-cell tumours, whereas the T-cell phenotype accounts for only $8 \%$ to $28 \%$ of cases $(11,16)$.

The pathogenesis of PHL remains unknown. Previous observations point toward underlying immune abnormalities in some patients. Thus, PHL has been associated with systemic lupus erythematosus (17), Felty's syndrome (18), primary biliary cirrhosis (19-21), organ transplantation and chemical immunosuppression (22). In addition, 15 cases of PHL in patients infected with the human immunodeficiency virus have been reviewed (8).

Chronic antigenic stimulation by viruses could be another mechanism of lymphomagenesis. Several cases of PHL in hepatitis B virus-infected patients have been described, 
$(11,16,23-26)$, but the virus has not been demonstrated in neoplastic cells per se $(24,25)$.

$\mathrm{HCV}$, another hepatotropic virus causing chronic liver disease, has been isolated from lymphocytes and lymphoid tissue $(26,27)$, and recently has been linked to non-Hodgkin's lymphoma in some, but not all, studies (28-31). Several cases of PHL associated with HCV infection have been reported (32-38). Using in situ hybridization, the HCV genome was detected recently in lymphoma cells of a patient with PHL, raising the possibility of direct oncogenic potential (38). Clearly, further investigations are needed to clarify the role

\section{REFERENCES}

1. Kim H, Dorfman RF, Rosenberg SA. Pathology of malignant lymphomas in the liver: Application in staging. In: Popper $\mathrm{H}$, Shaffner F, eds. Progress in Liver Disease. New York: Grune \& Stratton, 1976:683-98.

2. Chabner BS, Johnson RE, Chretien PB, et al. Percutaneous liver biopsy, peritoneoscopy and laparatomy: An assessment of relative merit in lymphomata. Br J Cancer 1975;31(Suppl 2):242-7.

3. Osborne BM, Butler JJ, Guardo LA. Primary lymphoma of the liver. Ten cases and a review of the literature. Cancer 1985;56:2902-10.

4. Dement SH, Mann RB, Staal SP, Kuhajda FP, Boitnott JK. Primary lymphomas of the liver. Report of six cases and review of the literature. Am J Clin Pathol 1987;88:255-63.

5. Ryan J, Straus DJ, Lange C, et al. Primary lymphoma of the liver. Cancer 1988;61:370-5.

6. Anthony PP, Sarsfield P, Clarke T. Primary lymphoma of the liver: clinical and pathological features of 10 patients. J Clin Pathol 1990;3:1007-13.

7. Scoazec JY, Degott C, Brousse N, et al. Non-Hodgkin's lymphoma presenting as a primary tumor of the liver: presentation, diagnosis and outcome in eight patients. Hepatology 1991;13:870-5.

8. Scerpella EG, Villareal AA, Casanova PF, Moreno JN. Primary lymphoma of the liver in AIDS. Report of one new case and review of the literature. J Clin Gastroenterol 1996;22:51-3.

9. Ata AA, Kamel IA. Primary reticulum cell sarcoma of the liver: a case report. J Egypt Med Assoc 1965;48:514-21.

10. Aghai E, Quitt M, Lurie M, et al. Primary hepatic lymphoma presenting as symptomatic immune thrombocytopenic purpura Cancer 1987;60:2308-11.

11. Lei KJK, Chow JHS, Johnson PJ. Aggressive primary hepatic lymphoma in Chinese patients. Cancer 1995;76:1336-43.

12. Scantosh-Kumar CR, Ajarim DSS, Shipkey FD. Primary non-Hodgkin's lymphoma of liver with humoral hypercalcemia. Postgrad Med J 1990;66:679-81.

13. Yasin M, Hartranft TH. Primary hepatic lymphoma: unusual presentation and clinical course. Am Surgeon 1997;63:951-3.

14. Brugiere O, Pialoux G, Carnot F, et al. Primary non-Hodgkin's lymphomas of the liver in human immunodeficiency virus infected patients. Three cases. Gastroenterol Clin Biol 1996;20:307-11.

15. Gazelle GS, Lee MJ, Hahn PF, Goldberg MA, Rafaat N, Mueller PR. US, CT, and MRI of primary and secondary liver lymphoma. J Comput Assist Tomogr 1994;18:412-5.

16. Aozasa K, Mishima K, Ohsawa M. Primary malignant lymphoma of the liver. Leuk Lymphoma 1993;10:353-7.

17. Sutton E, Malatjalian D, Hayne OA, Hanly JG. Liver lymphoma in systemic lupus erythematosus. J Rheumatol 1989;16:1584-8.

18. Bowman SJ, Levison DA, Cotter FE, Kingsley GH. Primary T cell lymphoma of the liver in a patient with Felty's syndrome. Br J Rheumatol 1994;33:157-60.

19. Goldin R, Sayer J, Wilkins M, Price P, Thomas H. Primary liver lymphoma associated with primary biliary cirrhosis. Histopathology 1993;22:184-5.

20. Prabhu RM, Medeiros LJ, Kumar D, et al. Primary hepatic low-grade B cell lymphoma of mucosa-associated lymphoid tissue (MALT) associated with primary biliary cirrhosis. Mod Pathol 1998:11:404-10.

21. Sato S, Masuda T, Oikawa H, et al. Primary hepatic lymphoma associated with primary biliary cirrhosis. Am J Gastroenterol 1999;94:1669-73.

22. Honda H, Franken EA, Barloon TJ, Smith JL. Hepatic lymphoma in of this virus in PHL. The patient described in this report had no serological markers for these viruses.

The optimal therapy for PHL remains unknown. In localized and respectable tumours, good long term results have been achieved with surgical extirpation alone or combined with chemotherapy $(3,5,6,39-41)$. Multiagent chemotherapy alone seems more appropriate in cases of diffuse infiltration and has led to prolonged remissions in some cases (3-6). Conversely, prognosis and response to treatment are poor in patients with extensive disease, coexisting liver disease or acquired immunodeficiency syndrome (7).

cyclosporine-treated transplant recipients: sonographic and CT findings. AJR Am J Roentgenol 1989;152:501-3.

23. Talamo TS, Dekker A, Gurecki J, Singh G. Primary hepatic malignant lymphoma: Its occurrence in a patient with chronic active hepatitis, cirrhosis, and hepatocellular carcinoma associated with hepatitis B viral infection. Cancer 1980;46:336-9.

24. Lisker-Melman M, Pittaluga S, Pluda JM, et al. Primary lymphoma of the liver in a patient with acquired immune deficiency syndrome and chronic hepatitis B. Am J Gastroenterol 1989;84:1445-8.

25. Matano S, Nakamura S, Annen Y, et al. Primary hepatic lymphoma in a patient with chronic hepatitis B. Am J Gastroenterol 1998;93:2301-2.

26. Zignego AL, Macchia D, Monti M, et al. Infection of peripheral mononuclear blood cells by hepatitis C virus. J Hepatol 1992;15:382.

27. Sansonno D, Jacobelli AR, Cornacchiulo V, Jodice G, Dammacco F. Detection of hepatitis $\mathrm{C}$ virus (HCV) proteins by immuno-fluorescence and HCV RNA genomic sequences by non-isotopic in situ hybridization in bone marrow and peripheral blood mononuclear cells chronically HCV-infected patients. Clin Exp Immunol 1996;103:414-21.

28. Pozzato G, Mazzaro C, Crovatto M, et al. Low grade malignant lymphoma, hepatitis $\mathrm{C}$ virus infection and mixed cryo-globulinemia. Blood 1994;84:3047-53.

29. Ferri C, Caracciolo F, Zignego AL, et al. Hepatitis $C$ virus infection in patients with non-Hodgkin's lymphoma. Br J Haematol 1994;88:392-4.

30. De Vita S, Sacco C, Sansonno D, et al. Characterizations of overt B-cell lymphomas in patients with hepatitis $\mathrm{C}$ virus infection. Blood 1997;90:776-82.

31. Collier JD, Zanke B, Moore M, et al. No association between hepatitis C and B cell lymphoma. Hepatology 1999;29:1259-61.

32. Ryan J, Wallace S, Jones P, Taggart G, Dudley F. Primary hepatic lymphoma in a patient with chronic hepatitis C. J Gastroenterol Hepatol 1994;9:308-10.

33. Morifa K, Hoshino H, Imada J, et al. Primary malignant lymphoma of the liver associated with cirrhosis induced by hepatitis $\mathrm{C}$ viral infection. Intern Med 1995;34:192-4.

34. Clarke G, MacMathuna P, Fenlon H, et al. Primary hepatic lymphoma in a man with chronic hepatitis C. Eur J Gastroenterol Hepatol 1997;9:87-90.

35. Andres E, Herbrecht R, Campos F, Marcellin L, Oberling F. Primary hepatic lymphoma associated with chronic hepatitis C. Ann Med Interne (Paris) 1997;148:280-3.

36. Bauduer F, Marty F, Gemain MC, Dulubac E, Bordahandy R. Primary non-Hodgkin's lymphoma of the liver in a patient with hepatitis B, C, HIV infections. Am J Hematol 1997;54:265.

37. Mohler M, Gutzler F, Kallinowski B, Goeser T, Stremmel W. Primary hepatic high-grade non-Hodgkin's lymphoma and chronic hepatitis $\mathrm{C}$ infection. Dig Dis Sci 1997;42:2241-5.

38. Ohsawa M, Tomita Y, Hashimoto M, Kanno H, Aozasa K. Hepatitis C viral genome in a subset of primary hepatic lymphomas. Mod Pathol 1998;11:471-8.

39. Andreola S, Andisio RA, Mazzaferro V, Doci R, Makowka L, Gennari L. Primary lymphoma of the liver showing immunohistochemical evidence of T-cell origin: successful management by right trisegmentectomy. Dig Dis Sci 1988;33:1632-6.

40. Ryoo JW, Manaligod JR, Walker MJ. Primary lymphoma of the liver. J Clin Gastroenterol 1986;8:308-11.

41. Yoneyama F, Nimura Y, Kamiya J, et al. Primary lymphoma of the liver with bile duct invasion and tumoral occlusion of the portal vein: report of a case. J Hepatol 1998;29:485-8. 


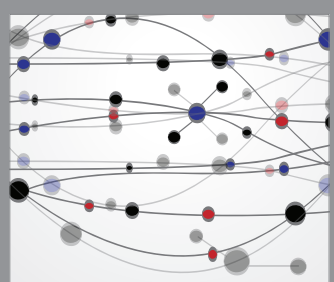

The Scientific World Journal
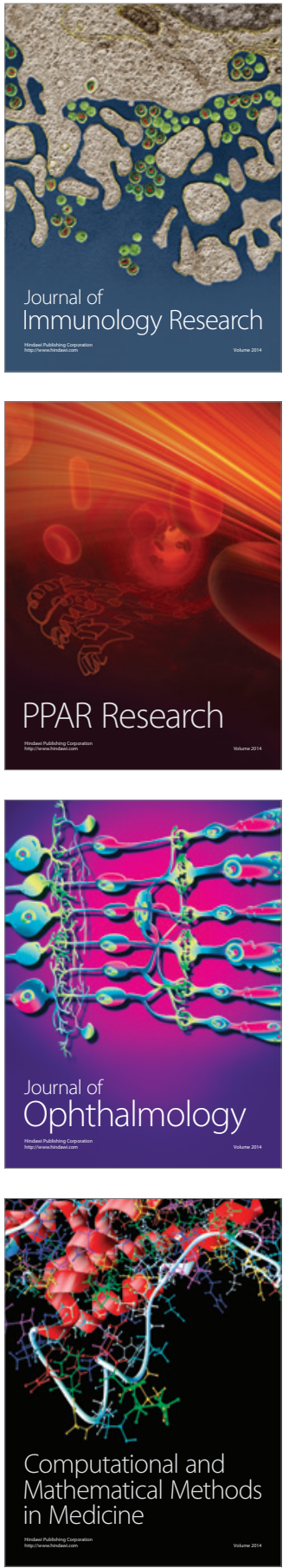

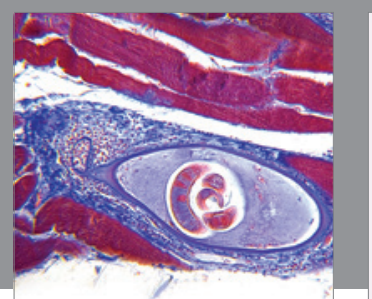

Gastroenterology Research and Practice

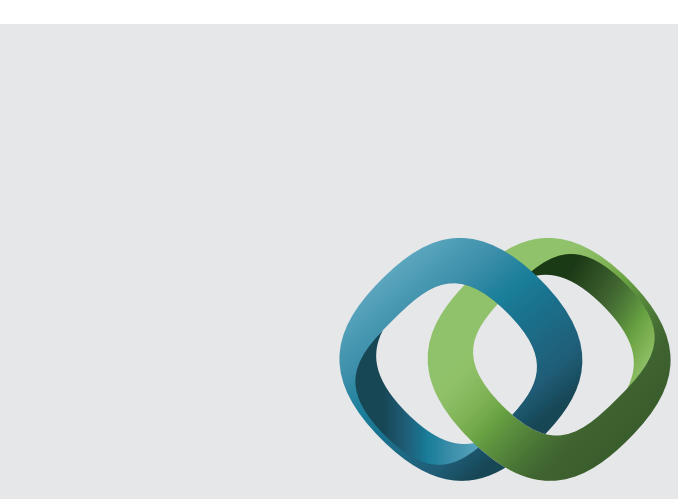

\section{Hindawi}

Submit your manuscripts at

http://www.hindawi.com
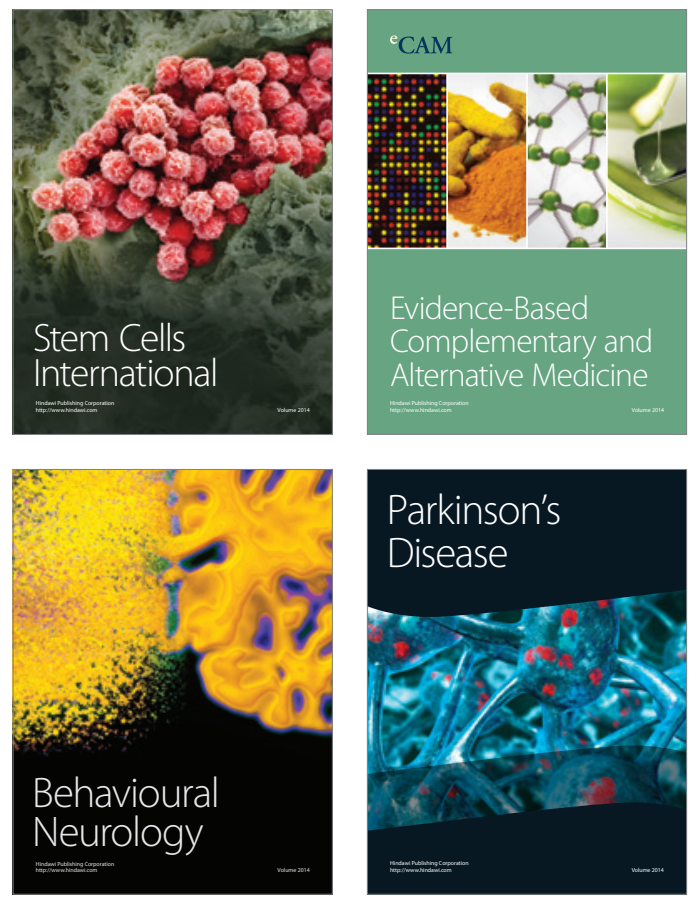
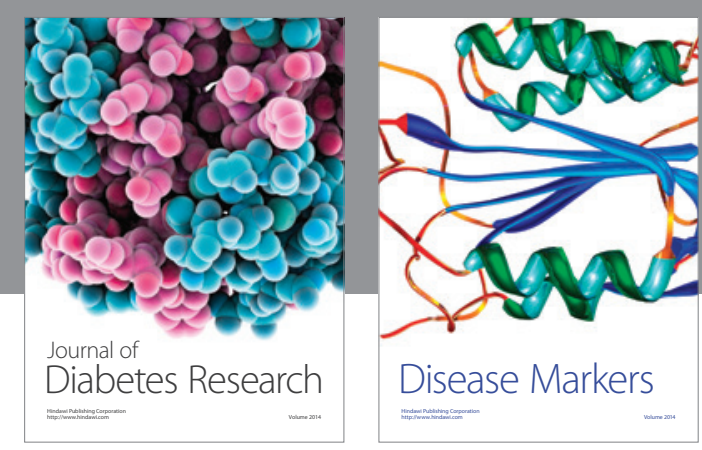

Disease Markers
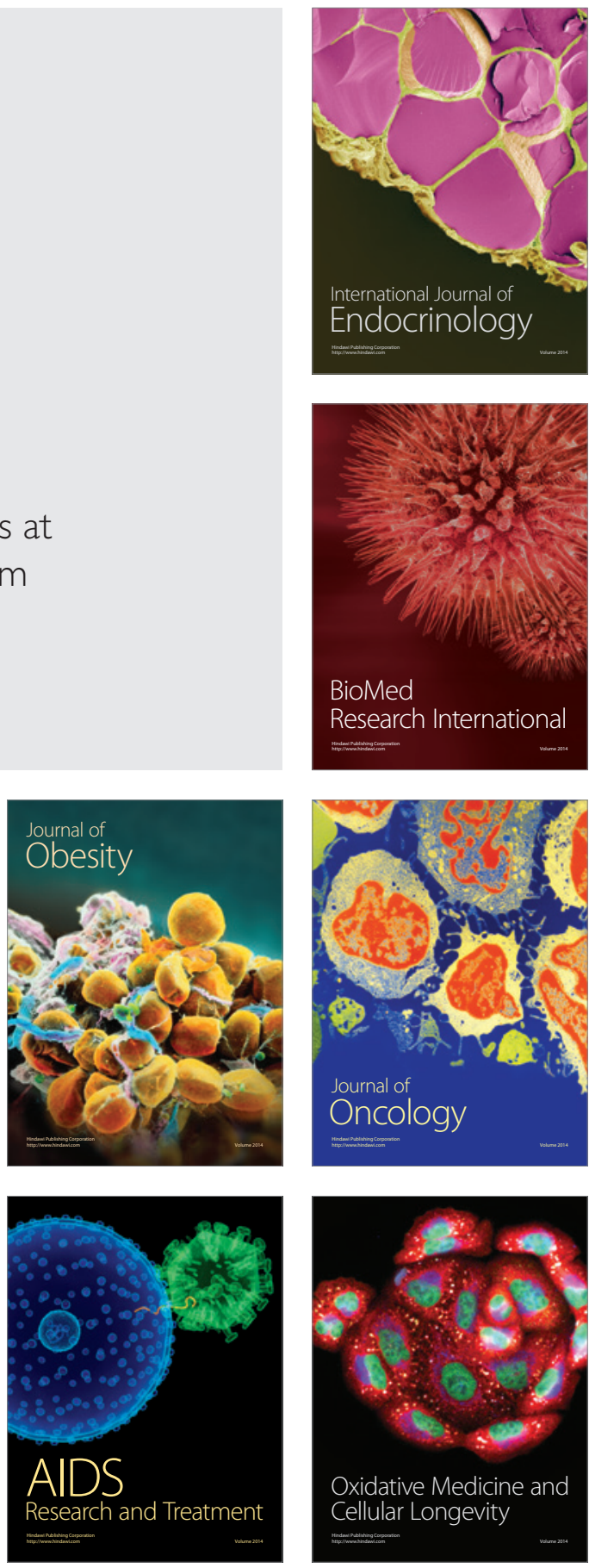